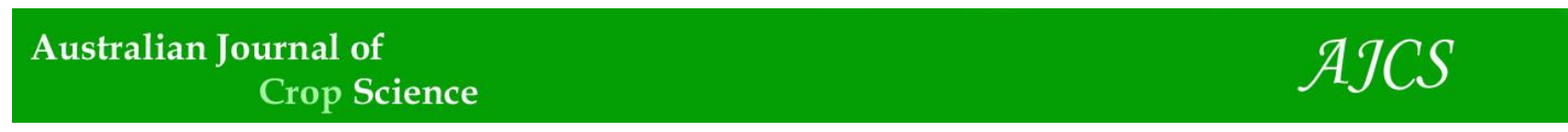

AJCS 12(06):980-984 (2018)

ISSN:1835-2707

doi: 10.21475/ajcs.18.12.06.PNE1086

\title{
Effect of chemical thinning using 6-benzyladenine (BA) on Maciel peach (Prunus persica L.)
}

\author{
Caroline Farias Barreto ${ }^{1 *}$, Renan Navroski ${ }^{1}$, Renan Ricardo Zandoná ${ }^{2}$, Roseli de Mello Farias ${ }^{1}$, Marcelo \\ Barbosa Malgarim ${ }^{1}$, Paulo Celso de Mello-Farias ${ }^{1}$
}

${ }^{1}$ Departamento de Fitotecnia, área de Fruticultura de Clima Temperado, Universidade Federal de Pelotas, Capão do Leão, RS, Brasil

${ }^{2}$ Departamento de Fitossanidade, Universidade Federal de Pelotas, Capão do Leão, RS, Brasil

*Corresponding author: carol_fariasb@hotmail.com

\begin{abstract}
High effective peach fruit set results in an excessive amount of fruits, requiring thinning accomplishment, which is a manual practice and demands specialized labor, raising production costs. In this sense, chemical thinning may be an alternative to improve the peach production chain. The objective of this work was to evaluate the efficiency of 6-benzyladenine (BA) on chemical thinning and the effect of different BA dosages on peach production and color characteristics of 'Maciel' fruits. Treatments consisted of plants without thinning (Control), sprayed BA at doses of $100 \mathrm{mg} \mathrm{L}^{-1}, 200 \mathrm{mg} \mathrm{L}^{-1}$ and $400 \mathrm{mg} \mathrm{L}^{-1}$, applied 45 days after full bloom (DAPF) and hand thinning at 45 DAPF. The applications of different dosages were carried out by spraying, using backpack spraying equipment. Percentage of thinning abscission, number of fruits per plant, yield per plant, fruit mass, color and average fruit diameter were evaluated. The doses of 200 and $400 \mathrm{mg} \mathrm{L}^{-1} \mathrm{BA}$ for thinning increased the percentage of fruit abscission and fruit mass. The doses of $400 \mathrm{mg} \mathrm{L}^{-1}$ BA presented lower yield per plant, but fruits with higher average mass. Increasing BA dose reduced the number of fruits per plant. Hand thinning and $400 \mathrm{mg} \mathrm{L}^{-1} \mathrm{BA}$ resulted peach fruits with larger diameter. BA application to thin peaches did not alter the fruit skin color. Therefore, BA may be a chemical thinning alternative for 'Maciel' peach cultivar, because it reduces the time of thinning in plants when compared to manual thinning. For an efficient chemical thinning with BA the product dose must be taken into account, along with climatic conditions and the cultivar.
\end{abstract}

Keywords: Abscission; hand thinning; fruit mass; plant growth regulators; production.

Abbreviations: BA 6-benzyladenine.

\section{Introduction}

The peach cultivars boast exuberant flowering in years of favorable weather conditions. High effective peach tree fruit set results in an excessive amount of peaches, being incompatible with plant productive capacity, producing small fruits and low commercial value (Giovanaz et al., 2016). Even with the plant self-regulation, causing fruits natural abscission by competing for carbohydrates and seed abortion, the reduction of fruit quantity is not sufficient for commercial quality production (Costa et al., 2005). In order to improve fruits quality and size, to increase the commercial value and to reduce the alternation of production, the practice of peach tree thinning should be carried out. Although it is a practice that provides several benefits, peach tree thinning is performed manually and it is an operation that requires high labor demand in a short period of time to make a high production cost (Mcartney et al., 2012; Simões et al., 2013). To reduce production costs, thinning techniques that use less manpower, such as chemical and mechanical thinning have been studied. Chemical thinning has tested products as such as 6benzyladenine (BA), metamitron and naphthalene acetic acid in apples (Petri et al., 2016; Goulart et al., 2017; Gabardo et al., 2017) and ammonium thiosulfate in cherry
(Schoedl et al., 2009). In peach trees, the tested products are BA, gibberellins and ethylene (Meitei et al., 2013; Giovanaz et al., 2014; Giovanaz et al., 2016); however, variations on results are reported according to the cultivar, product, season of application, product dose and climatic conditions of the growing site. BA has been tested as a chemical thinner mainly for apple trees (Petri et al., 2013, Petri et al., 2016, Goulart et al., 2017, Gabardo et al., 2017). It was observed that $B A$ reduces the effective fruit set in apple trees and higher concentrations are more effective in thinning (Petri et al., 2013). BA can provide fruit size increasing by the thinning effect and because it is a compound of the cytokinins group that acts enhancing the cellular division (Petri et al., 2013), and; therefore, has shown to be effective increasing fruits caliber. Due to this cell division increase, according to Greene (2005), BA can enhance fruit size even in the absence of thinning. Considering the high peach tree fruit set, hand thinning high production cost and a shortage of rural labor nowadays, it is important to deepen the knowledge of chemical thinning effect on peach fruits. However, there is still insufficient information about chemical thinning in peach tree crop, as well as the effect of BA used in the thinning in relation to productivity, fruit color and mass. Chemical thinning efficiency varies according to 
the product, cultivar, time of application and product dose. In this sense, the objective of this study was to evaluate the effect of different BA doses on chemical thinning in southern Brazil.

\section{Results and discussion}

\section{Percentage of fruit abscission and number of fruits per plant}

Percentage of peach fruits abscission was higher with BA dose increasing, in relation to the dose zero, that is, nonthinned plants (Fig 1). Therefore, the number of thinned fruits increasing by the use of chemical thinners directly affects manpower and reduction of production costs.

Applying hand peach thinning, a practice widely used in orchards, percentage of peaches abscission did not present statistical difference with BA doses of 100 and $200 \mathrm{mg} \mathrm{L}^{-1}$. Among $B A$ doses, $400 \mathrm{mg} \mathrm{L}^{-1}$ dose presented a higher percentage of Maciel cultivar fruits abscission. However, 'Jubilee' peach trees subjected to chemical thinning with 400 $\mathrm{mg} \mathrm{L}^{-1}$ BA dose at 40 DAPF presented excessive load and fruits with smaller diameter (Giovanaz et al., 2016). This fact suggests that there is variation of BA effect in peaches chemical thinning according to the cultivar.

The number of fruits per plant was decreased with increasing of BA dose, by which 200 and $400 \mathrm{mg} \mathrm{L}^{-1}$ doses resulted in 56.21 and $60.11 \%$ reduction, respectively, compared to control dose. At $200 \mathrm{mg} \mathrm{L}^{-1}$ dose, the same number of fruits per plant was obtained as in hand thinning, recommending this dose because the number of remained fruits after thinning was similar.

\section{Production per plant and mass of fruit}

Treatment control presented higher number of fruits per plant; however, resulted in fruits with lower mean mass (Fig 2) and lower diameter (Table 1). The highest number of fruits per plant and lower mass per fruit in non-thinned plants was also observed by McArtney et al. (2012) in an experiment testing different products in Imperial Gala apple chemical thinning.

The highest yield per plant was observed when chemical thinning with BA at $200 \mathrm{mg} \mathrm{L}^{-1}$ dose was used. They did not differ from hand thinning and $B A$ dose of $100 \mathrm{mg} \mathrm{L}^{-1}$. A lower yield per plant but higher average mass was observed in plants subjected to chemical thinning with BA dose of 400 $\mathrm{mg} \mathrm{L}^{-1}$. Fruit thinning may lead to reduced yield per plant, but increasing average fruit mass results in fruits with higher commercial value and may partially compensate yield loss determined by thinning (Stover et al., 2004).

The mean mass per fruit was higher when hand and chemical thinning were performed at 200 and $400 \mathrm{mg} \mathrm{L}^{-1}$ of BA. Fruits mean mass was increased when BA applied. It may be related to the cell division action, since cells number and size are determinants of final fruit size (Bertin et al., 2002; Hamada et al., 2008). Cultural practices such as plant's load reduction are one of the main tools to increase fruit size and mass (Tustin et al., 2012), because with plant load reduction, it decreases carbohydrates competition and improves photosynthesis products translocation among fruits (Byers et al., 2003).

\section{Classes of diameters of peach fruits}

Untreated plants (control) produced smaller fruits, with higher fruits percentage in the range of $45<55 \mathrm{~mm}$ in diameter (Table 1). Hand and chemical thinning with different BA doses did not present differences in the intermediate diameter class $(55<60 \mathrm{~mm})$. One of the main thinning objectives is to increase fruits size and to obtain fruits with higher caliber classes. Therefore, hand thinning and the dose of $400 \mathrm{mg} \mathrm{L}^{-1} \mathrm{BA}$ resulted in fruits with diameter between the classes $60>65 \mathrm{~mm}$ and $\geq 65 \mathrm{~mm}$.

According to Meitei et al. (2013), fruit size can be attributed to leaf/fruit ratio as act of thinning, increasing photosynthesis products and nutrients availability for fruits remaining in the plant, and thus increasing fruit size. Applying BA in 'Fuji Suprema' apple orchards, the proportion of larger fruits was observed. Fuji plants treated with $80 \mathrm{mg}$ $\mathrm{L}^{-1} \mathrm{BA}$ exhibited higher number of fruits with greater caliber (Petri et al., 2013).

\section{Fruit color}

The luminosity received in peaches skin was not influenced by treatments (Table 2). The smaller the coordinate $a^{*}$, the greener the fruit skin; thus, thinning treatments did not present statistical differences in the green coloration of peaches skin. Similarly to the other coloring parameters, ${ }^{\circ}$ Hue that expresses the color of the fruit itself did not show differences among tested treatments. The fact that BA does not alter peaches skin color and maintain similar to hand thinning, it becomes an effective product in not compromising fruits appearance and coloration for commercialization.

\section{Materials and methods}

\section{Plant materials}

A peach orchard of cultivar Maciel grafted on 'Capdeboscq' rootstock, implanted during 2006, with plants conduction system in " $V$ ", spaced $5 \mathrm{~m}$ between lines and $1.5 \mathrm{~m}$ between plants, totally 1,333 plants $\mathrm{ha}^{-1}$ density was used in this experiment.

\section{Location, climatic conditions and plant materials}

The experiment was conducted in an experimental orchard of Palma Agricultural Center, The Federal University of Pelotas (UFPel) in Capão do Leão, RS, latitude $31^{\circ} 52^{\prime} 00$ "S, longitude $52^{\circ} 21^{\prime} 24^{\prime \prime} \mathrm{W}$. The climate of region is characterized as humid temperate with hot summers according to the Köppen classification, type "Cfa" (Kottek et al., 2006). The region has an average annual temperature and rainfall of $17.9{ }^{\circ} \mathrm{C}$ and $1500 \mathrm{~mm}$, respectively. Temperature and mean precipitation during the experiment period are shown in Fig 3. During the year of 2016, 195 hours of cold was calculated on the basis of temperatures below or equal to $7.2{ }^{\circ} \mathrm{C}$. 
Table 1. Classes of diameters of 'Maciel' peach fruits submitted to chemical thinning with different BA doses and hand thinning fruits in the 2015/2016 harvest.

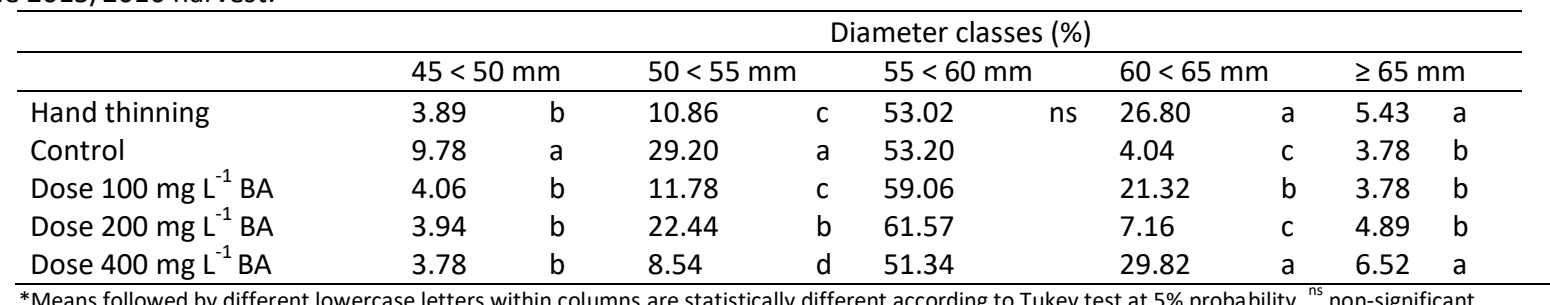
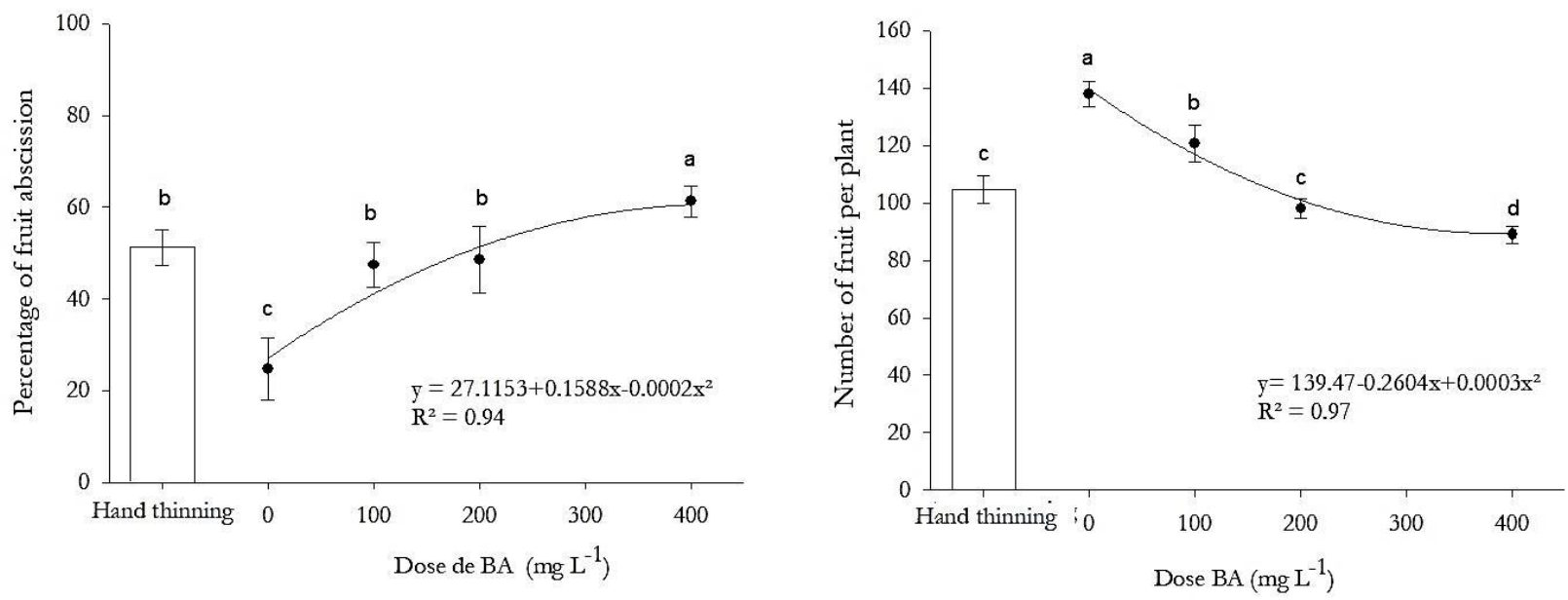

Fig 1. Percentage of fruit abscission and number of fruits per 'Maciel' peach plant subjected to chemical thinning with different BA doses and hand thinning fruits in the 2015/2016 harvest.

Table 2. Color of 'Maciel' peach fruits submitted to chemical thinning with different BA doses and hand thinning fruits in the 2015/2016 harvest.

\begin{tabular}{|c|c|c|c|c|c|c|}
\hline & Luminosity & & a* & & ${ }^{\circ}$ Hue & \\
\hline Hand thinning & 69.37 & ns & 2.27 & ns & 87.56 & ns \\
\hline Control & 70.52 & & 2.21 & & 87.64 & \\
\hline Dose $100 \mathrm{mg} \mathrm{L}^{-1} \mathrm{BA}$ & 69.50 & & 1.69 & & 88.24 & \\
\hline Dose $200 \mathrm{mg} \mathrm{L}^{-1} \mathrm{BA}$ & 69.78 & & 2.23 & & 87.62 & \\
\hline Dose $400 \mathrm{mg} \mathrm{L}^{-1} \mathrm{BA}$ & 68.46 & & 2.40 & & 87.38 & \\
\hline
\end{tabular}

${ }^{*}$ Means followed by different lowercase letters within columns are statistically different according to Tukey test at $5 \%$ probability. ${ }^{\text {ns }}$ non-significant.
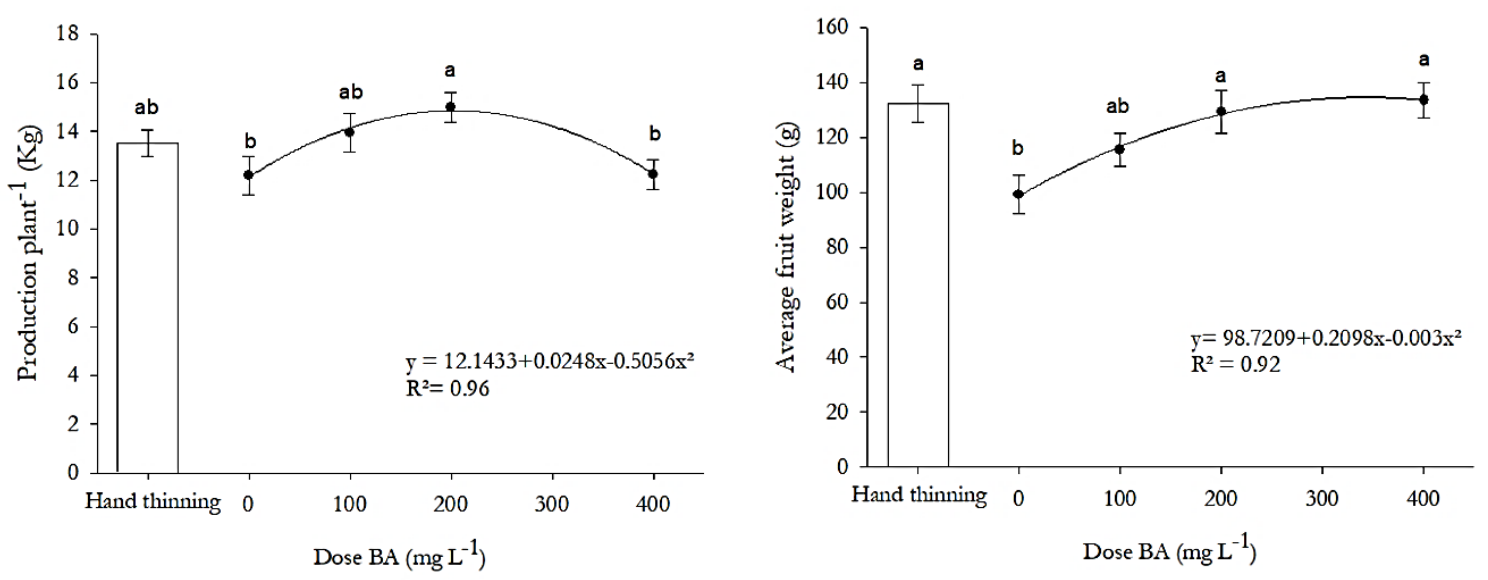

Fig 2. Production per plant and average mass of 'Maciel' peach trees submitted to chemical thinning with different BA doses and hand thinning fruits in the 2015/2016 harvest. 


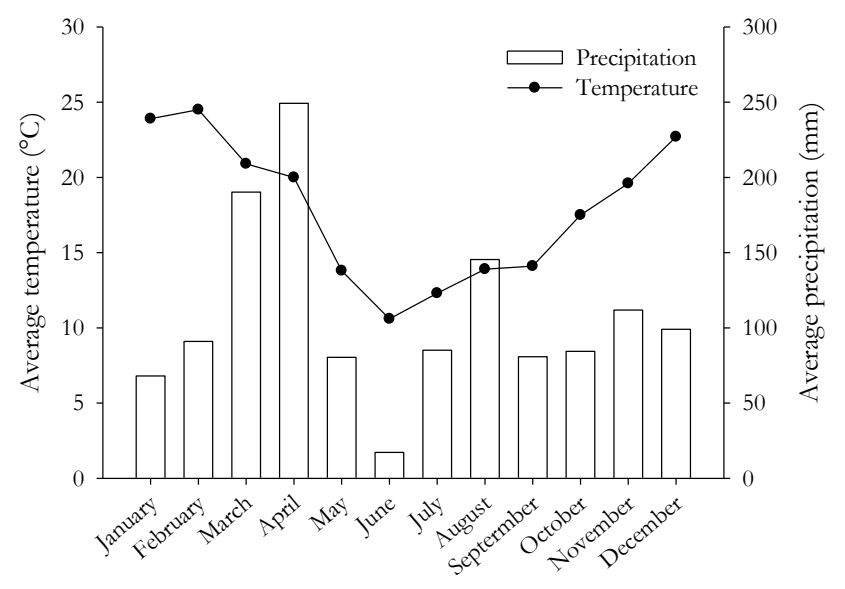

Fig 3. Average temperature and precipitation of the year 2016 for Capão do Leão, RS, Brazil. Experimental Station Terras Baixas, Embrapa Temperate Climate, in Capão do Leão town, RS, Brazil.

\section{Treatments and experimental design}

The experiment was conducted during 2016 in a randomized complete block design with five replicates of three plants per plot, evaluating the central plant. The treatments used were T1: Control (no chemical and hand thinning), T2: hand thinning at 45 DAPF, T3: application of BA at dose of $100 \mathrm{mg}$ L-1 at 45 DAPF; T4: application of BA at dose $200 \mathrm{mg} \mathrm{L}^{-1}$ at 45 DAPF; T5: application of BA at dose of $400 \mathrm{mg} \mathrm{L}^{-1}$ at 45 DAPF. MaxCel ${ }^{\circledR}$ commercial product ( $2 \%$ active ingredient - a.i.) was used as the source of BA. The sprayings were performed using a backpack sprayer, nozzles type JHC Jacto (Jacto, Pompeia, SP, Brazil), to the point of leaf wetting, with $1000 \mathrm{~L}$ $\mathrm{ha}^{-1}$ average water volume.

\section{Traits evaluated}

The following variables were evaluated in this experiment: percentage of fruits abscission in six branches previously randomly selected in each plant, the number of fruits before the trees thinning, the number of fruits at harvest time, number of fruits per plant, counting the fruits in the plant before harvest and production per plant (kg plant-1).

After harvesting, twenty peach fruits per replicate were evaluated for: average fruit mass, digital weighing and results expressed in grams (g); skin color, using a Minolta CR$300^{\circledR}$ colorimeter, with light source D65, where "L" (luminosity) readings were performed, "a*", "b*" and chromatic hue represented by the "hue angle"; fruits mean diameter, measured by digital caliper and results expressed in millimeters $(\mathrm{mm})$ and divided into five classes, $45<50$ $\mathrm{mm}, 50<55 \mathrm{~mm}, 55<60 \mathrm{~mm}, 60<65 \mathrm{~mm}$ and $\geq 65 \mathrm{~mm}$.

\section{Statistical analysis}

Data were evaluated for normality (Sharipo-Wilk test) and submitted to analysis of variance through the $F$ test. The means compared by Tukey test, where $p \leq 0.05$ and the doses showed significant. A regression analysis was conducted by Assistat (Silva and Azevedo, 2016).

\section{Conclusion}

Application of benzyladenine is an alternative to 'Maciel' peach cultivar fruits chemical thinning. Benzyladenine at 200 and $400 \mathrm{mg} \mathrm{L}^{-1}$ doses in peach thinning increased the percentage of abscission and fruit mass and does not alter the peaches coloration. Hand thinning and benzyladenine at $400 \mathrm{mg} \mathrm{L}^{-1}$ dose resulted in larger diameter fruits, but this dose reduced yield per plant. Benzyladenine at $200 \mathrm{mg} \mathrm{L}^{-1}$ dose as peach trees thinner provides fruit abscission similar to hand thinning and higher yield per plant.

\section{Acknowledgement}

To the Conselho Nacional de Desenvolvimento Científico e Tecnológico (CNPq) for financial support.

\section{References}

Bertin N, Gautier H, Roche C (2002) Number of cells in tomato fruit depending on fruit position and source-sink balance during plant development. Plant Growth Regul. 36:105-112.

Byers RE, Costa G, Vizzotto G (2003) Flower and fruit thinning of peach and other Prunus. Horticultural Reviews. 28:351-392.

Costa G, Dal Cin V, Ramina A (2005) Physiological, molecular and practical aspects of fruit abscission. Acta Hortic. 727:301-310.

Gabardo GC, Petri JL, Hawerroth FJ, Couto M, Argenta LC, Kretzschmar AA (2017) Use of metamitron as an apple thinner. Rev Bras Fruti. 39:e-514

Giovanaz MA, Amaral PA, Pasa MP, Lima APF, Weber D, Fachinello JC (2016) Chemical thinning affects yield and return flowering in 'Jubileu' peach. Rev. Ceres. 63:329-333.

Giovanaz MA, Fachinello JC, Goulart C, Radunz AL, Amaral PA, Weber D (2014) Produção e qualidade de pêssegos, cv. Jubileu, com uso de fitorreguladores. Rev Ceres. 61:552-557.

Goulart G, Aandrade SB, Bender A, Schiavon AV, Aguiar GA, Malgarim MB (2017) Metamitron and different plant growth regulators combinations in the chemical thinning of 'Eva' apple. J Exp Agric Intl. 18:1-6.

Greene DW (2014) Use of metamitron alone and in combination with 6-benzyladenine for thinning apples. Acta Hortic. 1042:167-172. 
Hamada K, Hasegawa K, Kitajima A, Ogata T (2008) The relationship between fruit size and cell division and enlargement in cultivated and wild persimmons. J Hortic Sci Biotech. 83:218-222.

Kottek M, Grieser J, Beck C, Rudolf B, Rubel F (2006) World Map of the Köppen-Geiger climate classification updated. Meteorol Z. 15:259-263.

Mcartney SJ, Obermiller JD, Arellano C (2012) Comparison of the effects of metamitron on chlorophyll fluorescence and fruit set in apple and peach. HortScience. 47:509-514.

Meitei SB, Patel RK, Deka BC, Deshmukh NA, Singh A (2013) Effect of chemical thinning on yield and quality of peach cv. Flordasun. Afr J Agr Res. 8:3358-3565.

Petri JL, Couto M, Gabardo GC, Francescatto P, Hawerroth JF (2016) Metamitron replacing carbaryl in post bloom thinning of apple trees. Rev Bras Fruti. 38:e-903.

Petri JL, Hawerroth FJ, Leite GB, Couto M (2013) Raleio químico em macieiras 'Fuji Suprema' e 'Lisgala'. Rev Bras Fruti. 35:170182.
Simões MP, Vuleta I, Belusic N (2013) Monda mecânica de flores com equipamento electro'flor em pessegueiros da cultivar 'Rich Lady'. Rev de Ciências Agrárias. 36:297-302.

Silva FAS, Azevedo CAV (2016) The Assistat software version 7.7 and its use in the analysis of experimental data. Afr J Agr Res. 11:3733-3740.

Schoedl K, Denk A, Hummelbrunne S, Modl P, Forneck A (2009) No improvement in fruit quality through chemical flower thinning in sweet cherry (Prunus avium L.). J Sci Food Agric. 89:1236-1240.

Stover E, Davis K, Wirth F (2004) Economics of fruit thinning: a review focusing on apple and citrus. HortTechnology. 14:282 289.

Tustin DS, Dayatilake GA, Breen KC, Oliver MJ (2012) Fruit set responses to changes in floral bud load - a new concept for crop load regulation. Acta Hortic. 932:195-202. 